Original Paper

\title{
Physico-chemical and Thermal Properties of Fuel Briquettes Derived from Biomass Furnaces as By-Products
}

\author{
Andres M. TUates ${ }^{\dagger}$, Aileen R. Ligisan, and Ofero A. CAPARIÑO
}

(Received November 24, 2015)

\begin{abstract}
Carbonized rice hulls $(\mathrm{CRH})$ and carbonized corn cobs (CCC) obtained during the utilization of PHilMech designed biomass furnaces were used as raw materials in the production of fuel briquettes. Two types of briquetting machines were used in the experiments and cassava starch was applied as binding agent during the formulation of samples. The briquettes were evaluated in terms of their physical and thermal properties. Results showed that the average density of $\mathrm{CRH}$ briquettes produced in screw-type machine was higher than the briquettes produced in piston-type machine. This observation can be attributed to the higher pressure applied in the screw-type machine. However, the briquettes made from the piston-type machine were found to be more durable compared to the one produced in screw-type machine, which can be associated with the high concentration of binding agent as required when using the piston-type machine. The optimum formulation using piston-type briquetting machine is $10 \%$ binding agent for $\mathrm{CRH}$ and $12.5 \%$ for CCC. For screw-type briquetting machine, $2.25 \%$ binding agent is ideal for both $\mathrm{CRH}$ and CCC. The resulting energy values and combustion qualities of the briquettes produced from the carbonized based fuel briquettes were sufficient to produce the required heat for industrial application.
\end{abstract}

\section{Key Words}

Carbonized materials, Fuel briquettes, Physical and thermal properties

\section{Introduction}

One of the important concerns that the Philippines and other developing countries are facing nowadays is the capability to have an affordable, dependable, and renewable energy source. Historically, the Philippines has been heavily dependent on imported oil for its energy needs. With the rising costs of fossil fuel energy coupled with the increasing population of the country, the pressure of harvesting alternative fuel options grow bigger every day.

The Philippines, being an agricultural country, has $43.3 \%$ total land area devoted to agricultural crops ${ }^{2}$. As a result, a large volume of agricultural residues and byproducts are generated annually but they are poorly utilized and badly managed since most of these wastes are left to decompose or they are burned, resulting in environmental pollution and degradation ${ }^{7}$.

Bioprocess Engineering Division, Philippine Center for Postharvest Development and Mechanization (PHilMech)

Science City of Muñoz, Nueva Ecija, Philippines

$\dagger \quad$ Corresponding author (amtuates@yahoo.com)
At PHilMech, biomass furnaces were developed and retrofitted to mechanical dryers as source of heat. The main objective of this project was to reduce the drying cost using mechanical dryers and to increase utilization of these types of dryers. Considering the potential economic benefits on this project, the Department Agriculture, through its FIELDS (fertilizer, irrigation and infrastructure, extension and education, loans and insurance, dryer and other postharvest facilities and seeds) program, led to intensify the utilization of biomass furnaces for mechanical dryers. However, the by-products derived during the utilization of the biomass furnace e.g. carbonized rice hull (CRH) or carbonized corn cobs (CCC) are now becoming a secondary waste problem due to their continuous accumulation within the drying area, which also creates pollution in the locality. One viable solution to this problem is to manage these carbonized materials by converting them into densified form or briquette. Briquetting is the process of converting low bulk density biomass into high density and energy concentrated fuel briquettes. Charcoal briquettes are 
good alternative sources of fuel. It can easily be ignited to produce heat or convert heat into fuel for domestic and industrial uses.

The general objective of the study is to determine the potential of carbonized materials derived from biomass furnaces as fuel briquettes. Specifically, it aims to: characterize the chemical properties of carbonized biomassbased fuel briquettes; determine the effect of sources of biomass by-product and binder proportions on the physical and thermal properties of fuel briquettes, and establish the optimum physical properties of the fuel briquettes.

\section{Methodology}

\subsection{Collection and source of experimental samples}

The carbonized materials were collected from PHilMech developed biomass furnaces i.e. Multi-Fuel Biomass Furnace (F1), Biomass-Fed Rice Hull Furnace/ Heater System (F2), Direct-Fired Rice Hull Furnace equipped with feeding auger (F3) and Direct-Fired Rice hull Furnace with step grate (F4).

\subsection{Proximate analysis and characterization of raw materials}

A representative sample of the carbonized material collected from different PHilMech developed furnaces were collected for proximate chemical analysis. The proximate chemical analysis (ASTM D-3172) was done at the Forest Products Research and Development Institute (FPRDI) of the Department of Science and Technology. The parameters include the moisture content, volatile combustible matter, fixed carbon, and ash.

\subsection{Production of briquettes}

The production of briquettes was conducted using piston-type (Fig. 1) and screw-type (Fig. 2) briquetting machines. For the Piston-type, the biomass was punched into a die by a reciprocating ram with a very high pressure thereby compressing the mass to obtain a compacted product.

While in the screw-type we used grooved barrels low-shear and high compression to enhance the mixing process. The rotating screw takes the material from the feed port, through the barrel, and compacted against a tapered die. The densified material was forced into intimate and substantially sliding contact with the barrel walls. Then it was forced through the extrusion die, where the briquette with shape was formed. Before reaching the compression zone the biomass gets partially compressed. The briquette that continuously comes out from the barrel was cut to a desired length using a slicer fixed at the end of the barrel.

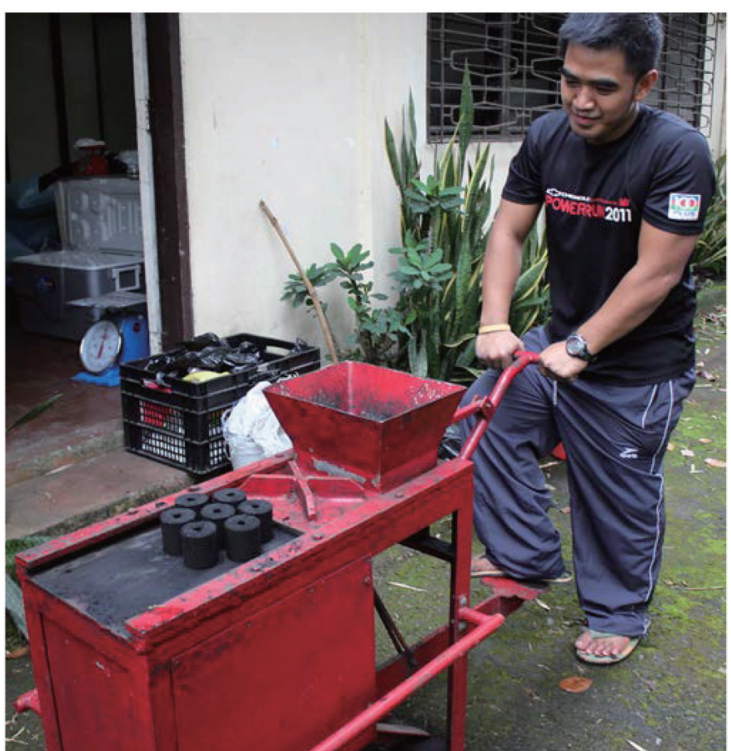

Fig. 1 Production of briquettes using the piston-type briquetting machine

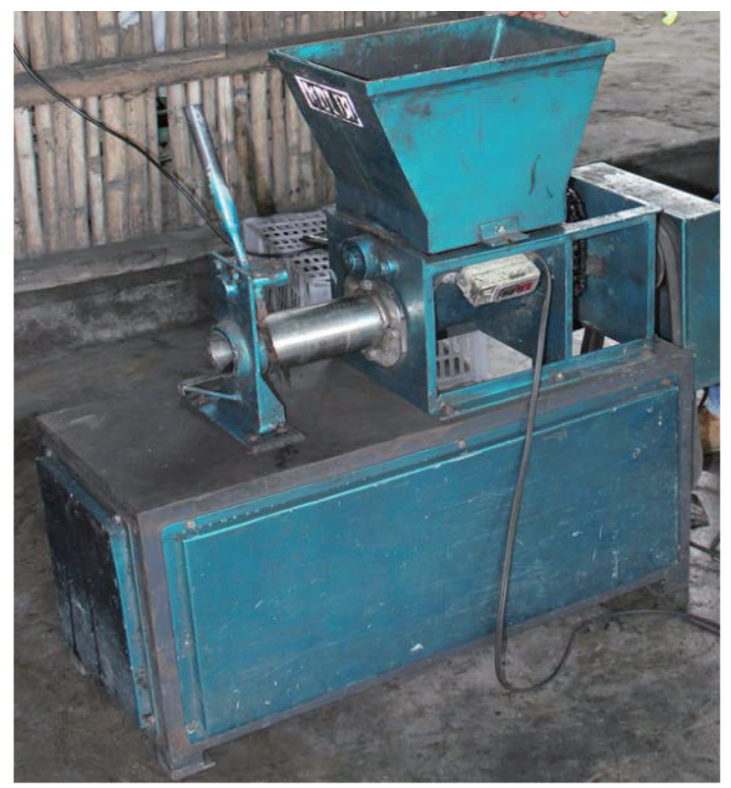

Fig. 2 The screw-type briquetting machine

The extruder-type briquetting machine is more appropriate in producing low-viscosity materials which prevents from clogging. A mechanical mixer and hammer mill were used to ensure the homogenous mixing of binder and carbonized materials.

Commercially available cassava starch was used as binder. This material is much cheaper than other binding agents, and it can easily be found in the local market. Another advantage of cassava starch is its excellent thickening characteristics. The binder ratio applied was based on the existing formulations used by the briquette producers. The Piston-type briquetting machine owner who 
produced briquettes from carbonized corn cobs used one liter of water and $100 \mathrm{~g}$ of starch, while the screw press type owner produced briquettes from water lily used two liters of water and $35 \mathrm{~g}$ of starch. Preliminary trial was conducted using a lower and higher amount of starch but the briquettes produced were weak, and the briquetting operation was erratic. Based from these preliminary results, the following percentage concentrations of binding agent were considered: $7.5 \%, 10 \%$ and $12.5 \%$ for piston-type and $1.75 \%, 2.00 \%$ and $2.25 \%$ for screw-type briquetting machine.

\subsection{Physical properties of briquette}

The physical properties such as density, shatter resistance, abrasive resistance and compression strength were evaluated and analyzed.

\subsubsection{Bulk density}

The bulk density of the produced fuel briquettes was determined by measuring the volume and weight of five (5) samples. Weighing was performed using the analytical balance (OHAUS) and the dimensions were measured using a vernier caliper. The density was calculated by determining the ratio of mass and volume of the material.

\subsubsection{Shatter resistance}

The shatter resistance was used to determine the resistance of the briquette to impact during handling and transport. The shatter resistance test may simulate the forces encountered during emptying of densified products from trucks onto ground, or from chutes into bins ${ }^{8)}$. The shatter resistance of briquettes was determined by following the procedure described by Ghorpade ${ }^{4}$. Representative briquettes from each formulation were selected for drop test. The briquette with known weight and dimensions was dropped on the concrete floor from the height of $1 \mathrm{~m}$. The weight of disintegrated briquettes and its size were recorded. The performance of the briquettes was generally expressed as the resistance to produce fine particles; which means, good performance would be indicated by greater mass fraction of $6.35 \mathrm{~mm}$ particles remaining after the drop tests. The shatter resistance of the briquettes was calculated using the following formula ${ }^{4)}$.

$$
\% \text { weight loss }=\frac{w_{1}-w_{2}}{w_{1}} \times 100
$$

$\%$ Shatter Resistance $=100-\%$ weight loss Where,

$w_{1}=$ weight of briquette before shattering

$w_{2}=$ weight of briquette after shattering

\subsubsection{Abrasive resistance}

A fabricated tumbler was used to test the resistance of the produced fuel briquettes to abrasion. A briquette with known weight was placed inside a tumbler rotating at the speed of $12 \mathrm{rpm}$ for $4 \mathrm{~min}$. After $4 \mathrm{~min}$ of tumbling action the briquette was taken out and weighed and the percentage loss was calculated using the formula of shatter resistance ${ }^{4)}$.

$$
\text { Weight loss }=\frac{w_{3}-w_{4}}{w_{3}} \times 100
$$

$\%$ Abrassive Resistance $=100-\%$ weight loss Where,

$w_{3}=$ Weight of briquette before tumbling

$w_{4}=$ Weight of briquette after tumbling

\subsubsection{Compressive strength}

Compressive resistance test simulates the compressive stress due to weight of the top briquettes on the lower briquettes during storage in containers. The hardness of the produced briquettes was determined using universal testing machine (INSTRON model). Compressive resistance of the densified products was determined by diametrical compression test. The flat surface of the briquette sample was placed on the horizontal metal plate of the machine. A $5 \mathrm{kN}$ load was applied at a cross head speed of $10 \mathrm{~mm} / \mathrm{min}$ until the briquette failed by cracking or breaking.

\subsection{Thermal properties of fuel briquettes \\ 2.5.1 Calorific value}

The calorific value is an indication of the energy the material possess as potential fuel. The calorific value of the produced briquettes was determined using LECO AC350. The test was done at the Forest Products Research and Development Institute (FPRDI) of the Department of Science and Technology.

\subsubsection{Energy density}

Clarke (2011) defined energy density as the term used to describe the amount of energy stored per unit volume ${ }^{1)}$. Compaction or densification is one way to increase the energy density.

\subsubsection{Thermal efficiency}

The thermal efficiency is otherwise known as percentage heat utilized or energy. This was measured using the water boiling test as described by Rathore (2008) ${ }^{14}$. The volume of the kettle was measured and filled by $2 / 3$ of water. The kettle with cover was placed on top of the charcoal stove. A thermometer was fixed in central part of kettle. $500 \mathrm{~g}$ of briquettes were measured for testing. The ambient temperature and initial temperature of water in the kettle were measured. Final temperature of water after boiling was observed. The water was heated until the briquettes were used up, then the kettle cover was removed and evaporation was continued for 20 minutes. Afterwards, 
the kettle was separated from the stove; the temperature of the kettle was lowered for 2 hours and the volume of water was measured. The thermal efficiency was calculated using the formula stated below. The numerator gives the net heat supplied to the water while the denominator gives the net heat liberated by the fuel.

$$
\text { Weight loss }=\frac{w_{3}-w_{4}}{w_{3}} \times 100
$$

Thermal Efficiency

$$
\begin{aligned}
& =\frac{\text { Sensible heat }+ \text { latent heat }}{\text { Quantity of fuel used } \times \text { calorific value }} \\
& =\frac{\mathrm{W}_{\mathrm{i}} \mathrm{Cp}\left(\mathrm{T}_{2}-\mathrm{T}_{1}\right)+\mathrm{L}\left(\mathrm{W}_{\mathrm{i}}-\mathrm{W}_{\mathrm{f}}\right)}{\text { Quantity of fuel used } \times \text { calorific value }}
\end{aligned}
$$
Where,

$\mathrm{W}_{\mathrm{i}}=$ initial volume of water, $\mathrm{kg}$,

$\mathrm{Cp}=$ specific heat of water, $\mathrm{J} / \mathrm{kg}{ }^{\circ} \mathrm{C}$

$\mathrm{T}_{2}=$ final temperature of water, ${ }^{\circ} \mathrm{C}$

$\mathrm{T}_{1}=$ initial temperature of water, ${ }^{\circ} \mathrm{C}$

$\mathrm{W}_{\mathrm{f}}=$ final volume of water, $\mathrm{kg}$

$\mathrm{L}=$ Latent heat of water $=2.26 \mathrm{MJ} / \mathrm{kg}(540 \mathrm{kcal} / \mathrm{kg})$

\subsection{Statistical analysis}

The data gathered was analyzed using $4 \times 3$ factorials in completely randomized design (CRD) for carbonized rice hull based fuel briquettes and simple for CRD for carbonized corn cobs based fuel briquettes. ANOVA table was utilized to determine the level of significant among treatments. The difference among means was analyzed using Duncan's Multiple Range Test (DMRT).

\section{Results and Discussion}

\subsection{Chemical properties of carbonized material}

Fig. 3 shows the chemical composition of carbonized materials obtained from PHilMech developed biomass furnaces by-products. The combustible volatile matter and fixed carbon content of biomass furnaces by-products obtained ranges from $8.68 \%$ to $10.73 \%$ and $14.88 \%$ to $82.78 \%$,

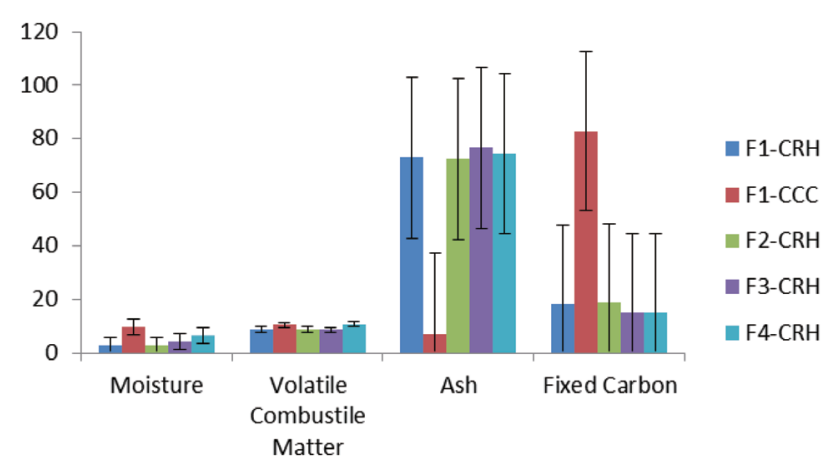

Fig. 3 Chemical composition of carbonized materials obtained from biomass-fed furnaces, (\%) respectively. The carbonized rice hull (CRH) derived from F4 has significantly high combustible volatile matter (10.73\%) compared to other $\mathrm{CRH}$ by-products. While significantly high amount of fixed carbon content (82.78\%) is evident on the carbonized corncob (CCC) derived from F1.

Incomplete combustion of corncobs from $\mathrm{F} 1$ could be due to the high temperature requirement of the drying operation when the sample collection was conducted. Typically, fast drying or drying at temperature ranging from 60-90 degrees Celsius is done to lower the moisture content of a commodity at shorter duration. In this type of drying operation, the biomass feed rate to the furnace is higher; thus, biomass such as corn cob was immediately discharged and not fully burned into ash. The obvious indication is that the carbonized corncobs derived from utilizing F1 still have adequate heating value and can be used as stand-alone source of energy while the $\mathrm{CRH}$ can be mix with coconut shell, sawdust, ricehull and among others to be sustainable.

\subsection{Physical properties of briquettes}

Fig. 4 shows the carbonized material-based fuel briquettes. The briquette is cylindrical in shape with hole in the center to promote efficient combustion. The size of briquette is $50 \mathrm{~mm}$ in length with an outside and inside diameter of $50 \mathrm{~mm}$ and $16 \mathrm{~mm}$, respectively. The briquettes were sundried from an initial moisture content of 43-51\% (wet basis) down to 6-8\% (wet basis). It is not advisable to dry the briquette below $6 \%$ because of possible moisture intake and expansion of the material. Li and Lui (2000) ${ }^{10)}$ reported that briquette with moisture content of $4 \%$ or lower become fragile due to expansion caused by moisture absorption.

\subsubsection{Bulk density}

The average bulk density of carbonized rice hull briquettes produced in screw-type was higher than pistontype (Tables 1 and 2), this could be due to the amount of pressure applied.

On the other hand, the bulk density of carbonized corn cob briquettes was higher than carbonized ricehull,

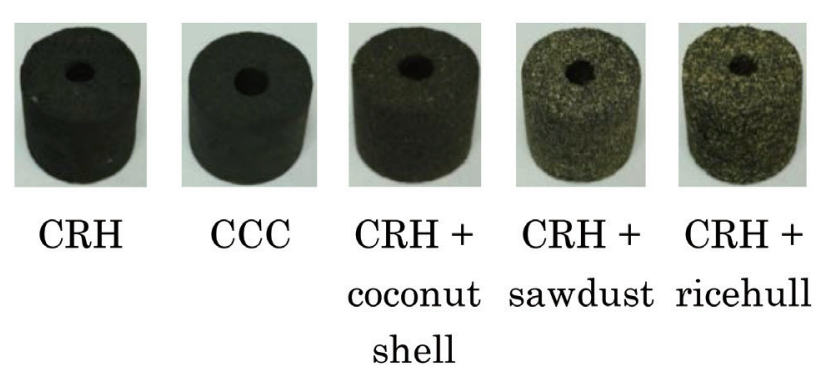

Fig. 4 The carbonized-based fuel briquettes 
Table 1 Bulk density of carbonized rice hull fuel briquettes, g/cc

\begin{tabular}{|c|c|c|c|c|c|c|c|c|}
\hline \multirow{3}{*}{$\begin{array}{c}\text { Source } \\
\text { of } \\
\text { CRH }\end{array}$} & \multirow{2}{*}{\multicolumn{3}{|c|}{$\begin{array}{c}\text { Piston-type } \\
\text { Binding Agent }\end{array}$}} & \multirow{3}{*}{ AVE } & \multirow{2}{*}{\multicolumn{3}{|c|}{$\begin{array}{c}\text { Screw-type } \\
\text { Binding Agent }\end{array}$}} & \multirow{3}{*}{ AVE } \\
\hline & & & & & & & & \\
\hline & $7.5 \%$ & $10 \%$ & $12.5 \%$ & & $1.75 \%$ & $2.0 \%$ & $2.25 \%$ & \\
\hline $\mathrm{F} 1$ & 0.41 & 0.46 & 0.47 & $0.45^{c}$ & 0.59 & 0.62 & 0.68 & $0.63^{b}$ \\
\hline $\mathrm{F} 2$ & 0.39 & 0.43 & 0.44 & $0.42^{\mathrm{d}}$ & 0.57 & 0.62 & 0.64 & $0.61^{\mathrm{b}}$ \\
\hline F3 & 0.46 & 0.47 & 0.49 & $0.47^{b}$ & 0.56 & 0.68 & 0.76 & $0.67^{\text {a }}$ \\
\hline $\mathrm{F} 4$ & 0.43 & 0.58 & 0.61 & $0.54^{\mathrm{a}}$ & 0.67 & 0.71 & 0.69 & $0.69^{\mathrm{a}}$ \\
\hline AVE & $0.42 \mathrm{c}$ & $0.49 \mathrm{~b}$ & $0.50 \mathrm{a}$ & 0.47 & $0.60 \mathrm{c}$ & $0.66 \mathrm{~b}$ & $0.69 \mathrm{a}$ & 0.65 \\
\hline
\end{tabular}

Average or means with the same superscript letters within column indicate no significant difference $(\mathrm{p}<0.05)$

Table 2 Bulk density of carbonized corn cobs fuel briquettes, g/cc

\begin{tabular}{cccccccccc}
\hline Binding & \multicolumn{3}{c}{ Piston-type } & \multirow{2}{*}{ AVE } & Binding & \multicolumn{3}{c}{ Screw-type } & \multirow{2}{*}{ AVE } \\
\cline { 2 - 3 } Agent & R1 & R2 & R3 & & Agent & R1 & R2 & R3 & \\
\hline $7.5 \%$ & 0.52 & 0.54 & 0.56 & $0.54^{\mathrm{c}}$ & $1.75 \%$ & 0.52 & 0.52 & 0.52 & $0.52^{\mathrm{b}}$ \\
$10 \%$ & 0.65 & 0.62 & 0.64 & $0.64^{\mathrm{b}}$ & $2.0 \%$ & 1.31 & 1.26 & 1.25 & $1.27^{\mathrm{a}}$ \\
$12.5 \%$ & 0.73 & 0.71 & 0.74 & $0.73^{\mathrm{a}}$ & $2.25 \%$ & 1.32 & 1.31 & 1.27 & $1.30^{\mathrm{a}}$ \\
\hline
\end{tabular}

Average or means with the same superscript letters within column indicate no significant difference (p $<0.05)$

this could be due to its particle size and pores space. Carbonized corn cob was ground using a hammer mill to pass $3.20 \mathrm{~mm}$ sieve and was pulverized further during mixing and making it finer. The fine particles make compaction process easier, provide less pore spaces and more mass of the material per given volume ${ }^{11}$. In addition, Tumuluru and co-workers (2010) also reported that smaller particle size produces denser products ${ }^{18)}$.

The analysis of variance revealed significant differences $(p<0.05)$ on the sources of carbonized material and the amount of binding agent applied. This can be attributed to the different features and operations of existing biomass furnaces. For instance, F1 and F2 have auto feeder but during the process the biomass by-products are directed to the holding bin allowing for a continued burning process. F4 has similar auto feeder mechanism but the obtained by-product passes through the watering chamber that stops burning of rice hull. The by-product produced in the method was porous. However, the pores within the particles may have been filled by the semi-fluid binder which has enhanced the bonding between particles during densification process. Due to the application of high pressure, particles are brought close together, causing inter-particle attraction forces which make solid bridges between the particles ${ }^{9}$. . Moreover, adding more binder leads to increased briquette density as observed using screw type briquetting machine for carbonized corn cobs. The briquette density value was influenced not only by material composition and binding agent ratio but also by the type of briquetting machine used.

\subsubsection{Impact resistance}

The highest \% impact resistance obtained of $\mathrm{CRH}$ and CCC fuel briquettes using piston type and screw type briquetting machine was $88.45 \%$ and $85.32 \%$ and $92.83 \%$ and $97.61 \%$, respectively (Tables 3 and 4). The highest percent impact resistance was obtained in fuel briquettes produced using screw type briquetting machine. This can be associated to the high amount of starch required in the formulation of briquettes.

Percent impact resistance is significantly different ( $p<0.05$ ) on carbonized material sourced from F1. During collection of samples it was observed the F1 furnace produced finer $\mathrm{CRH}$ compared to other furnaces because of the continuous burning after discharging its by-product. The number of contact points between particles is higher in fine materials than in large particles; so, the finer the material, the larger it's exposed surface area ${ }^{13)}$. Higher impact resistance was observed on carbonized rice hull briquettes made using piston-type than in using screw-type briquetting machine. This could be attributed to higher proportion of binding agent formulated for piston-type briquetting machine. Briquettes made from carbonized corn cob also exhibited high impact resistance. This was expected as these briquettes have higher bulk density compared to those made from carbonized rice hull. Increase in compressed density and binder level enhances durability ${ }^{12)}$.

\subsubsection{Abrasive Resistance}

The highest percent abrasive resistance was obtained in piston-type briquetting machine both for the carbonized rice hull or corn cobs fuel briquettes (Tables 5 and 6). The high amount of binding agent in the formulation increased 
Table 3 Percent impact resistance of carbonized rice hull fuel briquettes, \%

\begin{tabular}{|c|c|c|c|c|c|c|c|c|}
\hline \multirow{3}{*}{$\begin{array}{l}\text { Source } \\
\text { of } \mathrm{CRH}\end{array}$} & \multirow{2}{*}{\multicolumn{3}{|c|}{$\begin{array}{l}\text { Piston-type } \\
\text { inding Agent }\end{array}$}} & \multirow{3}{*}{ AVE } & \multirow{2}{*}{\multicolumn{3}{|c|}{$\begin{array}{c}\text { Screw-type } \\
\text { Binding Agent }\end{array}$}} & \multirow{3}{*}{ AVE } \\
\hline & & & & & & & & \\
\hline & $7.5 \%$ & $10 \%$ & $12.5 \%$ & & $1.75 \%$ & $2.0 \%$ & $2.25 \%$ & \\
\hline $\mathrm{F} 1$ & 85.94 & 86.71 & 87.71 & 86.79 & 83.78 & 85.83 & 86.35 & $85.32^{\mathrm{a}}$ \\
\hline $\mathrm{F} 2$ & 78.33 & 87.99 & 88.95 & 85.09 & 67.52 & 73.73 & 80.96 & $74.07^{\mathrm{b}}$ \\
\hline F3 & 87.60 & 88.34 & 89.42 & 88.45 & 54.77 & 72.49 & 85.41 & $70.89^{b}$ \\
\hline $\mathrm{F} 4$ & 86.51 & 87.01 & 87.76 & 87.09 & 56.33 & 58.31 & 84.41 & $66.35^{\mathrm{b}}$ \\
\hline AVE & $84.60^{\mathrm{b}}$ & $87.51^{\mathrm{a}}$ & $88.46^{\mathrm{a}}$ & 86.86 & 65.60 & 72.59 & 84.28 & 74.16 \\
\hline
\end{tabular}

Average or means with the same superscript letters within column indicate no significant difference $(\mathrm{p}<0.05)$

Table 4 Percent impact resistance of carbonized corn cobs fuel briquettes, \%

\begin{tabular}{cccccccccc}
\hline Binding & \multicolumn{3}{c}{ Piston-type } & \multirow{2}{*}{ AVE } & Binding & \multicolumn{3}{c}{ Screw-type } & \multirow{2}{*}{ AVE } \\
\cline { 2 - 3 } \cline { 7 - 8 } & R1 & R2 & R3 & & Agent & R1 & R2 & R3 & \\
\hline $7.5 \%$ & 87.64 & 86.53 & 89.80 & $87.99^{\mathrm{b}}$ & $1.75 \%$ & 93.57 & 87.05 & 86.53 & $89.05^{\mathrm{b}}$ \\
$10 \%$ & 93.73 & 92.66 & 90.82 & $92.40^{\mathrm{a}}$ & $2.0 \%$ & 92.38 & 91.29 & 93.11 & $92.20^{\mathrm{b}}$ \\
$12.5 \%$ & 93.83 & 91.92 & 92.74 & $92.83^{\mathrm{a}}$ & $2.25 \%$ & 95.82 & 98.05 & 98.97 & $97.61^{\mathrm{a}}$ \\
\hline
\end{tabular}

Average or means with the same superscript letters within column indicate no significant difference $(\mathrm{p}<0.05)$

Table 5 Percent abrasive resistance of carbonized rice hull fuel briquettes, \%

\begin{tabular}{|c|c|c|c|c|c|c|c|c|}
\hline \multirow{3}{*}{$\begin{array}{l}\text { Source } \\
\text { of } \mathrm{CRH}\end{array}$} & \multirow{2}{*}{\multicolumn{3}{|c|}{$\begin{array}{l}\text { Piston-type } \\
\text { Binding Agent }\end{array}$}} & \multirow{3}{*}{ AVE } & \multirow{2}{*}{\multicolumn{3}{|c|}{$\begin{array}{c}\text { Screw-type } \\
\text { Binding Agent }\end{array}$}} & \multirow{3}{*}{ AVE } \\
\hline & & & & & & & & \\
\hline & $7.5 \%$ & $10 \%$ & $12.5 \%$ & & $1.75 \%$ & $2.0 \%$ & $2.25 \%$ & \\
\hline $\mathrm{F} 1$ & 95.21 & 95.50 & 99.09 & $96.60^{c}$ & 91.55 & 97.2 & 97.60 & $95.45^{a}$ \\
\hline $\mathrm{F} 2$ & 98.81 & 99.61 & 99.83 & $99.41^{\text {a }}$ & 79.46 & 80.18 & 80.98 & $80.20^{c}$ \\
\hline F3 & 93.27 & 94.20 & 94.71 & $94.06^{\mathrm{d}}$ & 41.34 & 55.97 & 72.40 & $56.57^{\mathrm{d}}$ \\
\hline F4 & 96.71 & 98.26 & 99.15 & $98.04^{b}$ & 82.59 & 87.30 & 91.29 & $87.06^{b}$ \\
\hline AVE & $96.00^{c}$ & $96.89^{b}$ & $98.20^{\mathrm{a}}$ & 97.03 & 73.74 & 80.16 & 85.57 & 79.82 \\
\hline
\end{tabular}

Average or means with the same superscript letters within column indicate no significant difference $(\mathrm{p}<0.05)$

Table 6 Percent abrasive resistance of carbonized corn cobs fuel briquettes, \%

\begin{tabular}{cccccccccc}
\hline Binding & \multicolumn{3}{c}{ Piston-type } & \multirow{2}{*}{ AVE } & Binding & \multicolumn{3}{c}{ Screw-type } & \multirow{2}{*}{ AVE } \\
\cline { 2 - 3 } \cline { 7 - 8 } & R1 & R2 & R3 & & Agent & R1 & R2 & R3 & \\
\hline $7.5 \%$ & 99.38 & 99.59 & 99.80 & 99.59 & $1.75 \%$ & 96.26 & 96.76 & 96.34 & $96.45^{\text {b }}$ \\
$10 \%$ & 99.44 & 99.59 & 99.77 & 99.60 & $2.0 \%$ & 98.46 & 99.02 & 97.56 & $98.34^{\text {a }}$ \\
$12.5 \%$ & 98.03 & 98.44 & 99.61 & 98.69 & $2.25 \%$ & 99.33 & 98.24 & 98.25 & $98.61^{\text {a }}$ \\
\hline
\end{tabular}

Average or means with the same superscript letters within column indicate no significant difference $(\mathrm{p}<0.05)$

the abrasive resistance of the produced briquette.

The analysis of variance revealed significant differences $(\mathrm{p}<0.05)$ on the sources of carbonized material and percentage composition of binding agent. This can be associated to the characteristics of by-product produced of furnaces. It was observed the F1 furnace produced finer $\mathrm{CRH}$ compared to other furnaces because of the continuous burning after discharging its by-product. Moreover, carbonized corn cob was pulverized by means of a hammer mill. Shaw (2008) reported that in densification, milling the material will provide a larger surface area for bonding since this will increase the porosity of the bulk material ${ }^{15)}$.

\subsubsection{Compression test}

The compressive test was a criterion of briquette durability. The highest breaking load $(1.02 \mathrm{kN})$ was obtained in briquettes with highest proportion of binding agent and made using piston-type (Tables 7 and 8). This can be associated to its requirement of high amount of binding agent to produced fuel briquettes. High viscous bonding media are good hardening binders ${ }^{5}$. Moreover, there are no standard criteria on the acceptance level for strength of the densified products made from biomass materials ${ }^{8}$. 
Table 7 Compressive breaking point of arbonized rice hull fuel briquettes, $\mathrm{kN}$

\begin{tabular}{|c|c|c|c|c|c|c|c|c|}
\hline \multirow{3}{*}{$\begin{array}{l}\text { Source } \\
\text { of } \mathrm{CRH}\end{array}$} & \multirow{2}{*}{\multicolumn{3}{|c|}{$\begin{array}{c}\text { Piston-type } \\
\text { Binding Agent }\end{array}$}} & \multirow{3}{*}{ AVE } & \multirow{2}{*}{\multicolumn{3}{|c|}{$\begin{array}{c}\text { Screw-type } \\
\text { Binding Agent }\end{array}$}} & \multirow{3}{*}{ AVE } \\
\hline & & & & & & & & \\
\hline & $7.5 \%$ & $10 \%$ & $12.5 \%$ & & $1.75 \%$ & $2.0 \%$ & $2.25 \%$ & \\
\hline $\mathrm{F} 1$ & 0.05 & 0.09 & 0.10 & $0.08^{c}$ & 0.03 & 0.06 & 0.08 & $0.06^{\mathrm{a}}$ \\
\hline $\mathrm{F} 2$ & 0.06 & 0.11 & 0.13 & $0.10^{\mathrm{b}}$ & 0.01 & 0.02 & 0.03 & $0.02^{\mathrm{b}}$ \\
\hline F3 & 0.11 & 0.18 & 0.24 & $0.18^{\mathrm{a}}$ & 0.01 & 0.03 & 0.03 & $0.02^{b}$ \\
\hline F4 & 0.03 & 0.08 & 0.12 & $0.08^{c}$ & 0.05 & 0.06 & 0.08 & $0.06^{\mathrm{a}}$ \\
\hline AVE & $0.06 \mathrm{c}$ & $0.12 b$ & $0.15 \mathrm{a}$ & 0.11 & 0.03 & 0.04 & 0.06 & 0.04 \\
\hline
\end{tabular}

Average or means with the same superscript letters within column indicate no significant difference $(\mathrm{p}<0.05)$

Table 8 Compressive breaking point of carbonized corn cobs fuel briquettes, kN

\begin{tabular}{cccccccccc}
\hline Binding & \multicolumn{3}{c}{ Piston-type } & \multirow{2}{*}{ AVE } & Binding & \multicolumn{3}{c}{ Screw-type } & \multirow{2}{*}{ AVE } \\
\cline { 2 - 3 } \cline { 7 - 8 } Agent & R1 & R2 & R3 & & Agent & R1 & R2 & R3 & \\
\hline $7.5 \%$ & 0.41 & 0.50 & 0.48 & $0.46^{\mathrm{b}}$ & $1.75 \%$ & 0.09 & 0.10 & 0.09 & 0.09 \\
$10 \%$ & 0.55 & 0.66 & 0.57 & $0.59^{\mathrm{b}}$ & $2.0 \%$ & 0.09 & 0.09 & 0.09 & 0.09 \\
$12.5 \%$ & 1.13 & 0.93 & 1.00 & $1.02^{\mathrm{a}}$ & $2.25 \%$ & 0.08 & 0.09 & 0.09 & 0.09 \\
\hline
\end{tabular}

Average or means with the same superscript letters within column indicate no significant difference $(\mathrm{p}<0.05)$

The analysis of variance revealed significant differences $(\mathrm{p}<0.05)$ on the source of carbonized material and the amount of binder used. Several researchers reported that it was difficult to obtain repeatability of the results from the compressive resistance test for the same quality of pellets/briquettes ${ }^{3)}{ }^{10)}$ 16) 177. However, increase in breaking load of briquettes made using piston type was observed. This can be associated to the high amount of binding agent used. Increase in the amount of starch would also indicate increase in binding agent's viscosity. According to Kaliyan and co-workers, highly viscous binders such as starch adhere to the surfaces of solid particles to generate strong bonds that are very similar to those of solid bridges ${ }^{8}$. Many viscous binders harden after cooling and form solid bridges.

\subsection{Thermal properties of briquettes}

\subsubsection{Heating value}

Fig. 5 shows the heating value of carbonized rice hull (CRH) based fuel briquettes and carbonized corn cobs (CCC). The heating value of carbonized corn cobs and carbonized rice hull are $21.08 \mathrm{MJ} / \mathrm{kg}$ and $4.81 \mathrm{MJ} / \mathrm{kg}$, respectively. Likewise, the heating value of carbonized ricehull blended with other biomass are coconut shell; $11.40 \mathrm{MJ} / \mathrm{kg}$, sawdust; $12.40 \mathrm{MJ} / \mathrm{kg}$, ricehull; $10.60 \mathrm{MJ} / \mathrm{kg}$, and corn cobs; $15.55 \mathrm{MJ} /$ $\mathrm{kg}$. Lee (2007) cited that to sustain combustion, a heating value of $11.63 \mathrm{MJ} / \mathrm{kg}$ or greater is needed. This gives a positive indication of the suitability of $\mathrm{CCC}$ and $\mathrm{CRH}$ blended briquettes as substitute fuel to wood charcoal.

\subsubsection{Energy density}

Fig. 6 shows the energy density of rice hull, corn

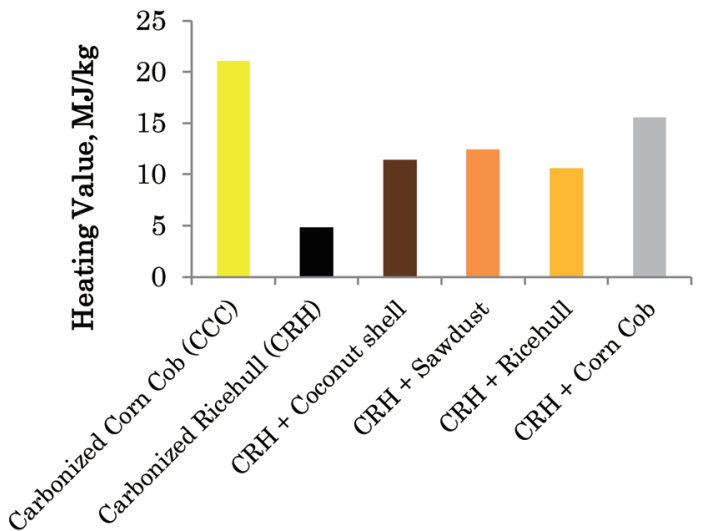

Fig. 5 Heating value of fuel briquettes, $\mathrm{MJ} / \mathrm{kg}$

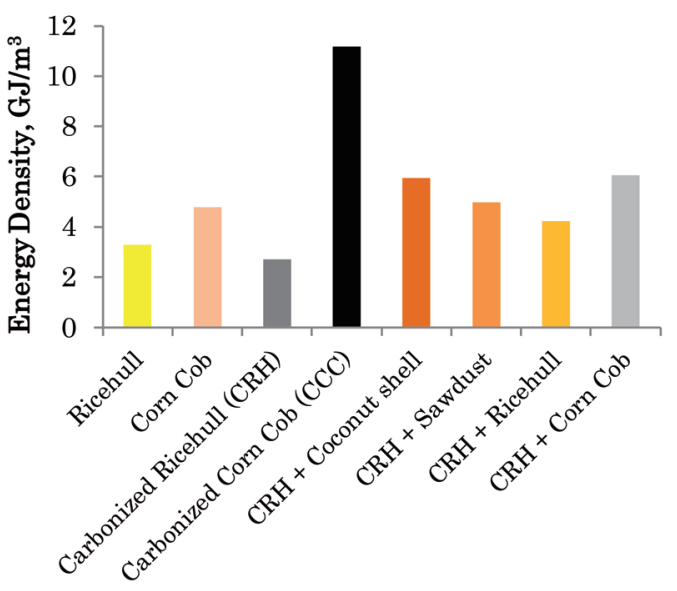

Fig. 6 Energy Density of fuel briquettes, $\mathrm{GJ} / \mathrm{m}^{3}$ 


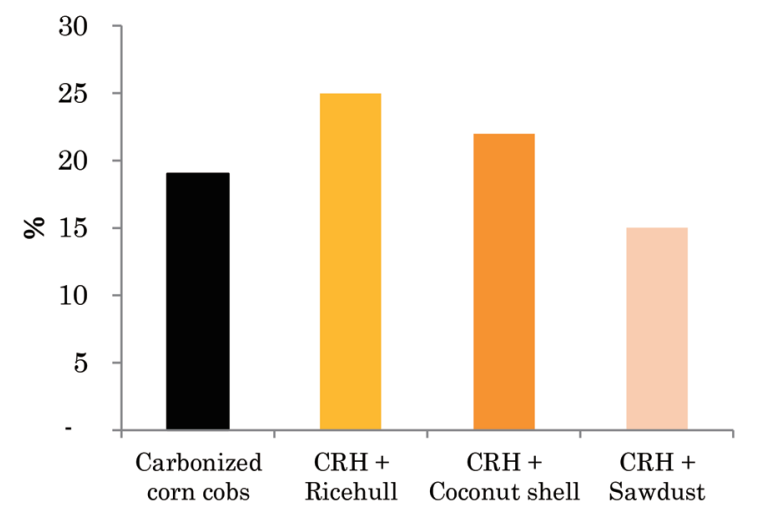

Fig. 7 Thermal efficiency using carbonized biomass-based briquettes, \%

cobs, carbonized rice hull (CRH), carbonized corn cobs and $\mathrm{CRH}$ blended with other biomass. Carbonized corn cobs and $\mathrm{CRH}$ blended with other biomass obtained higher energy density than rice hull and corn cobs. This can be attributed to the high density of carbonized based fuel briquettes. It was also observed that blending of carbonized rice hull in other biomass improved the physical quality of the fuel briquettes, reduced the production of smoke and facilitated the blue flame during water boiling test.

\subsubsection{Thermal Efficiency}

The fuel briquettes produced from carbonized corn cobs can boil water in 9 minutes and did not produced smoke, this can be attributed to its low volatile matter content (10.3\%). Ivanov and co-workers ${ }^{6)}$ reported that fuels related to smokeless grade are known to contain no more than $20 \%$ volatile substances. For the CRH based briquettes, smoke was observed during ignition but vanished as flame developed. Result of boiling tests showed that CRH blended briquettes required 8-10 minutes to boil $1.6 \mathrm{~L}$ of water. The thermal efficiency of briquettes obtained were carbonized corn cobs (19.02\%), CRH+Ricehull (25\%), $\mathrm{CRH}+$ Coconut shell (22\%) and CRH+Sawdust (15\%) as shown in Fig. 7.

\section{Conclusions}

The highest density, percent shatter resistance, percent abrasive resistance and compression strength of $\mathrm{CRH}$ and CCC based fuel briquettes using piston type and screw type briquetting machine were $0.58 \mathrm{~g} / \mathrm{cc}$ and $0.76 \mathrm{~g} /$ cc, $0.74 \mathrm{~g} / \mathrm{cc}$ and $1.32 \mathrm{~g} / \mathrm{cc} ; 89.42 \%$ and $86.35 \%, 92.83 \%$ and $97.61 \% ; 99.83 \%$ and $97.60 \%, 99.60 \%$ and $98.25 \% ; 0.24 \mathrm{kN}$ and $0.08 \mathrm{kN}, 1.13 \mathrm{kN}$ and $0.10 \mathrm{kN}$, respectively.

The heating value of carbonized corn cobs (CCC) based fuel briquettes are $21.08 \mathrm{MJ} / \mathrm{kg}$ while the carbonized ricehull based fuel briquettes mixed with coconut shell are $11.40 \mathrm{MJ} / \mathrm{kg}$, sawdust (12.40 MJ/kg), ricehull (10.56 MJ/ $\mathrm{kg})$, and corn cobs $(15.55 \mathrm{MJ} / \mathrm{kg})$. The fuel briquettes can boil water in 8-10 minutes and did not produced smoke. Likewise, the thermal efficiency of briquettes obtained were carbonized corn cobs (19.02\%), CRH+Ricehull (25\%), $\mathrm{CRH}+$ Coconut shell (22\%) and CRH+Sawdust (15\%). Carbonized corn cobs and CRH blended with other biomass obtained higher energy density than rice hull and corn cobs.

Based on the foregoing results, the following conclusions can be drawn:

- The optimum formulation using piston-type briquetting machine is $10 \%$ binding agent for carbonized ricehull and $12.5 \%$ for carbonized corn cob. For screw-type briquetting machine, $2.25 \%$ binding agent is ideal for both $\mathrm{CRH}$ and CCC.

- The carbonized materials derived from PHilMech biomass furnaces can be utilized to produce high quality briquette with high durability rating and heating value.

- The energy values and combustion qualities of the briquettes produced in this study are sufficient enough to produce the required heat for domestic cooking and also for industrial application.

\section{References}

1) Clarke, S., Biomass densification for energy production, Ministry of Agriculture, Food and Rural Affairs, Ontario Canada, 2011

2) Department of Agriculture, DA online data, 2012, http://da.gov.ph, retrieved April 2012

3) Franke, M.; Rey, A., Pelleting quality, World Grain May 2006, 78-79, 2006

4) Ghorpade, S. S.; Moule, A. P., Performance Evaluation of Deoiled Cashew Shell Waste for Fuel Properties in Briquetted Form, B.Tech. Thesis (unpub.), Dapoli, 15, 2006

5) Grover, P. D.; Mishra, S. K., Biomass Briquetting, Technology and Practices, Regional Wood Energy Development Programme in Asia, Field document No. 46 Bangkok, Thailand, FAO, 1996

6) Ivanov I. P.; Sudakova, I. G.; Kuznetsovv, B., Chem. Sustai. Devel., 11, 847-852 (2003)

7) Jekayinfa, S. O.; Omisakin, O. S., The Energy Potentials of some agricultural wastes as local fuel materials in Nigeria. Agricultural Engineering International: CIGR Ejournal of Scientific Research and Development Vol. VII, Manuscript EE 05 003, 10p., 2005

8) Kaliyan, N.; Morey, R. V., Biomass and Bioenergy, 33, 337-359 (2009)

9) Karunanithy, C.; Wang, Y.; Muthukumarappan, K.; Pugalendhi, S., Physiochemical Characterization of Briquettes Made from Different Feedstocks, Biotech Research Int., 2012, 12 (2012) 
10) Li, Y.; Liu, H., Biomass and Bioenergy, 19, 177-186 (2000)

11) Maninder; Rupinderjit, S. K.; Sonia, G., IOSR Journal of Electrical and Electronics Engineering (IOSRJEEE), 1(5),11-15 (2010), ISSN: 2278-1676

12) Olorunnisola, A., Production of fuel briquettes from waste paper and coconut husk admixtures. Agricultural Engineering International: the CIGR E journal, Manuscript EE 06 006, Vol. IX, February 2007

13) Peleg, M.; Mannheim, C. H., Powder Technology, 7, 45-50 (1973)

14) Rathore, N. S.; Panwar, N. L., Renewable Energy Theory and Practice, Himanshu Publication, New delhi, p. 273,2008
15) Shaw, M., Feedstock and Process Variables Influencing Biomass Densification, MS thesis, University of Saskatchewan, Department of Agricultural and Bioresource Engineering, University of Saskatchewan Press, 2008

16) Tabil, L., Jr.; Sokhansanj, S., Applied Eng. In Agric., 12(3), 345-350 (1996)

17) Thomas, M.; van Zuilichem, D. J.; van der Poel, A. F. B., Animal Feed Sci. Tech., 64, 173-192 (1997)

18) Tumuluru, J. S.; Wright, C. T.; Kenny, K. L.; Hess, J. R., A Review on Biomass Densification Technologies for Energy Application, 2010, available at http://www.inl. aov 